\title{
Underrepresentation of Phenotypic Variability of 16p13.11 Microduplication Syndrome Assessed With an Online Self-Phenotyping Tool (Phenotypr): Cohort Study
}

Jianqiao Li ${ }^{1,2^{*}}$, MSc; Margaret A Hojlo ${ }^{3,4 *}$, BA; Sampath Chennuri ${ }^{5}$, MSc; Nitin Gujral ${ }^{5}$, MBA, MSc; Heather L Paterson $^{1,2}$, BSc; Kent A Shefchek ${ }^{6}$, MSc; Casie A Genetti ${ }^{1,2}$, MSc; Emily L Cohn ${ }^{5}$, MPH; Kara C Sewalk ${ }^{7}$, MPH; Emily A Garvey $^{3,4}$, BA; Elizabeth D Buttermore ${ }^{8}, \mathrm{PhD}$; Nickesha C Anderson ${ }^{9}$, PhD; Alan H Beggs ${ }^{1,2,10}$, PhD; Pankaj B Agrawal ${ }^{1,2,10,11}$, MD, MMSc; John S Brownstein ${ }^{5,10}, \mathrm{PhD}$; Melissa A Haendel ${ }^{12}$, PhD; Ingrid A Holm ${ }^{1,2,10}$, MD, MPH; Joseph Gonzalez-Heydrich ${ }^{2,3,4,13^{*}}, \mathrm{MD}$; Catherine A Brownstein ${ }^{1,2,40^{*}}, \mathrm{MPH}, \mathrm{PhD}$

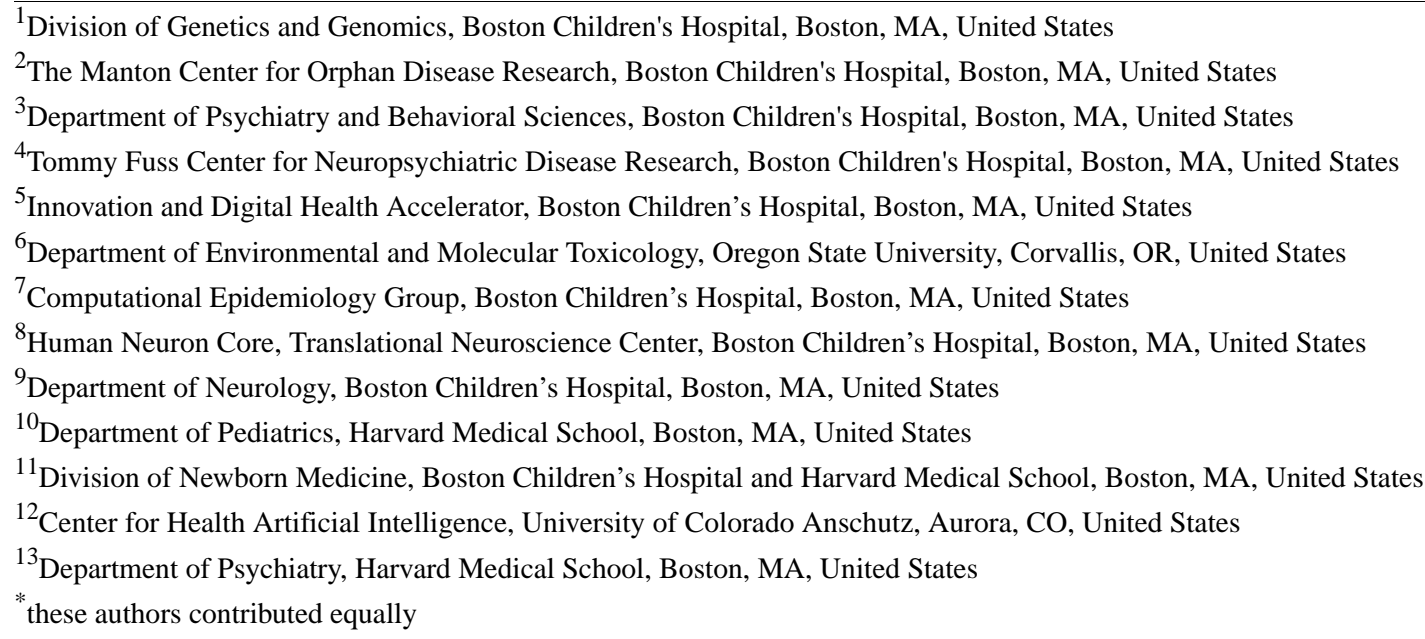

\section{Corresponding Author:}

Catherine A Brownstein, MPH, PhD

Division of Genetics and Genomics

Boston Children's Hospital

300 Longwood Avenue

Boston, MA, 02115

United States

Phone: 16173554764

Email: catherine.brownstein@ childrens.harvard.edu

\section{Abstract}

Background: $\quad 16$ p13.11 microduplication syndrome has a variable presentation and is characterized primarily by neurodevelopmental and physical phenotypes resulting from copy number variation at chromosome 16p13.11. Given its variability, there may be features that have not yet been reported. The goal of this study was to use a patient "self-phenotyping" survey to collect data directly from patients to further characterize the phenotypes of 16p13.11 microduplication syndrome.

Objective: This study aimed to (1) discover self-identified phenotypes in 16p13.11 microduplication syndrome that have been underrepresented in the scientific literature and (2) demonstrate that self-phenotyping tools are valuable sources of data for the medical and scientific communities.

Methods: As part of a large study to compare and evaluate patient self-phenotyping surveys, an online survey tool, Phenotypr, was developed for patients with rare disorders to self-report phenotypes. Participants with 16p13.11 microduplication syndrome were recruited through the Boston Children's Hospital 16p13.11 Registry. Either the caregiver, parent, or legal guardian of an affected child or the affected person (if aged 18 years or above) completed the survey. Results were securely transferred to a Research Electronic Data Capture database and aggregated for analysis. 
Results: A total of 19 participants enrolled in the study. Notably, among the 19 participants, aggression and anxiety were mentioned by $3(16 \%)$ and $4(21 \%)$ participants, respectively, which is an increase over the numbers in previously published literature. Additionally, among the 19 participants, $3(16 \%)$ had asthma and $2(11 \%)$ had other immunological disorders, both of which have not been previously described in the syndrome.

Conclusions: Several phenotypes might be underrepresented in the previous 16p13.11 microduplication literature, and new possible phenotypes have been identified. Whenever possible, patients should continue to be referenced as a source of complete phenotyping data on their condition. Self-phenotyping may lead to a better understanding of the prevalence of phenotypes in genetic disorders and may identify previously unreported phenotypes.

(J Med Internet Res 2021;23(3):e21023) doi: $\underline{10.2196 / 21023}$

\section{KEYWORDS}

self-phenotyping; 16p13.11 microduplication syndrome; copy number variation; genetics; incomplete penetrance; phenotype; variable presentation; human phenotype ontology; online survey; digital health

\section{Introduction}

16p13.11 microduplication syndrome is a rare chromosome duplication syndrome associated with copy number variation (CNV) at the chromosome 16p13.11 locus. The syndrome has high variability in phenotype. Clinical case reports have shown that patients with 16p13.11 microduplication (dup16p13.11) may experience intellectual disability, speech delay, and emotional and behavioral disorders like attention-deficit/hyperactivity disorder (ADHD) and autism spectrum disorder (ASD) [1-4]. Other neurodevelopmental phenotypes related to this CNV include perinatal hypotonia and feeding difficulties, gross motor delay, epilepsy, and schizophrenia [1,3,5]. Abnormal brain magnetic resonance imaging findings have also been described [1-4]. Additional medical conditions related to $16 \mathrm{p} 13.11$ microduplication include cardiovascular disease, as well as a range of congenital abnormalities of varying severity including pulmonary stenosis, coarctation of the aorta, thoracic aortic aneurysm dissection, hypermobile joints, hand/foot deformities, microcephaly and macrocephaly, umbilical hernia, and vision problems such as strabismus, myopia, and amblyopia [4,5].

There are considerable challenges in predicting the clinical outcomes of those with 16p13.11 microduplication. For one, there is incomplete penetrance in which both affected and unaffected members from the same family have been found to carry the same CNV, while de novo cases also occasionally occur [2-5]. In addition, variable expressivity of the dup16p13.11 phenotypes may occur as a result of the size of the duplication, reportedly ranging from several kilobases to a few megabases. A majority of the known 16p13.11 microduplications include duplication of the gene NDE1, which has long been suggested as the primary candidate gene for the neurological and behavioral phenotypes in affected patients [1,4,6-8]

A potentially powerful approach to understanding the complex phenotypic spectrum of $16 \mathrm{p} 13.11$ microduplication syndrome is to collect phenotypic data from patients themselves (or their caregivers), as they experience the symptoms and effects of their condition. GenomeConnect, the National Institutes of Health-funded Clinical Genome Resource (ClinGen) patient registry, developed a patient self-phenotyping survey, which asks patient-friendly questions that have been mapped to a set of high-level human phenotype ontology (HPO) terms [9-11]. HPO is a standardized vocabulary of phenotypic abnormalities encountered in human disease, whereby symptoms and characteristic phenotypic findings (a phenotypic profile) are captured using a logically constructed hierarchy of phenotypic terms [12,13]. An alternative method for self-phenotyping is for patients to generate HPO terms for their condition directly. Our group developed a "layperson" HPO survey called "Phenotypr" to capture patient phenotypes by translating most standard HPO terms into layperson language that would be easy for patients to comprehend and use (eg, a layperson term for "hypotonia" would be "muscle weakness") $[14,15]$. We tested the GenomeConnect and Phenotypr surveys computationally and in patients with known rare diseases.

Here, we describe the results of a subset of participants in the larger study who had 16p13.11 microduplication syndrome and completed the Phenotypr survey. The primary aim was to determine if there were self-identified phenotypes that were underrepresented in previous reports of patients with 16p13.11 microduplication syndrome.

\section{Methods}

\section{Recruitment}

Participants were the caregivers, parents, or legal guardians of individuals with $16 \mathrm{p} 13.11$ microduplication or the affected individuals themselves, and were aged 18 years or older. Individuals with $16 \mathrm{p} 13.11$ microduplication were recruited through the Boston Children's Hospital online 16p13.11 Participant Registry. Individuals who had previously joined the Registry and self-reported a 16p13.11 microduplication diagnosis were sent an informational email about the Phenotypr study. In addition, a blurb about the study that included research team contact information was posted on 16p13.11 microduplication Facebook groups, and potential participants contacted us directly. Participants received a US \$15 Amazon gift card for completing the Phenotypr survey. Participants provided chromosomal microarray reports to confirm diagnoses. The study was approved by the Boston Children's Hospital Institutional Review Board. 


\section{Phenotypr Survey Development}

We developed Phenotypr as a freely available tool that allows patients to record their conditions in layperson and medical HPO terms (see examples of the completion process in Figures 1-3). In Phenotypr, patients first selected the body systems affected by their condition. Seventeen body system options were provided, such as "Growth," "Ears/Hearing," and "Brain/Nervous System." Participants then typed out their symptoms into the symptom search tool, with search result filters applied based on the body systems that they had selected. Tips for entering symptoms were provided, such as reminders to be as specific as possible and include conditions not local to a certain body part (eg, sensitivity to pain). Phenotypr autocompleted each entry with the layperson HPO term, as well as the standard HPO term, and partitioned the terms into anatomically specific sections. The survey ended with a brief demographics form and open-text feedback boxes. Once the survey was complete, the list of the standard HPO terms that corresponded to the layperson HPO terms was downloadable in PDF format.

Phenotypr consisted of a back-end administrative tool for updating ontology versions, user and administrative permissions, and support for alternative implementations; a front-facing public site; and a back-end relational Research Electronic Data Capture (REDCap) database for securely housing the data [16]. Ontology autocomplete features were implemented by processing the HPO and loading structured data into an Apache Solr search engine [17]. The user interface was implemented as a single page application with Vue.js [18].

Figure 1. Data entry for Phenotypr: relevant body system selection.

\section{PHENOTYPR Body Tool}

\section{BODY: SELECT BODY SYSTEM / CATEGORY}

\section{Please choose all of the categories of symptoms that apply to you \\ $\checkmark$ Growth}

For example you are much shorter or taller than expected for your family, you have had ...

Show more

\section{Hormone / Endocrine}

Eg. Diabetes, thyroid issues, reduced functioning of the gonads (ovaries or testes) with ...

Show more

\section{Cancer}

Any type, any time. Examples: Breast cancer, prostate cancer, osteosarcoma, or lymph...

Show more

$\mathrm{Head} / \mathrm{Face} / \mathrm{Neck}$

Parts of your head, face, and neck that may be different, in terms of its appearance or h...

Show more

$\checkmark$ Eyes / vision

Examples: Vision loss, cataracts, or "lazy eye." You may have seen an optometrist or op...

\section{Ears / hearing}

\section{Show more}

Examples: Hearing loss, ringing in the ears, or misshapen ears. You may have seen an a...

Show more

Brain / nervous system

Examples: Developmental delays, intellectual disability, learning problems, seizures, sig...

Show more

Behavioral / psychiatric

Examples: Autism spectrum disorders, schizophrenia, anxiety, aggression, repetitive be... 
Figure 2. Data entry for Phenotypr: symptom search tool.

\section{PHENOTYPR Body Tool}

\begin{tabular}{|c|c|c|}
\hline Enter your symptoms (do not & & \multirow{4}{*}{$\begin{array}{l}\text { About this Search } \\
\text { Your search will be filtered by the } \\
\text { categories you selected: Growth, } \\
\text { Eyes / vision, Brain / nervous } \\
\text { system, Behavioral / psychiatric }\end{array}$} \\
\hline behav| & $x$ & \\
\hline Repetitive or self-injurious behavior & & \\
\hline \multicolumn{2}{|l|}{ Restricted behavior } & \\
\hline \multicolumn{3}{|l|}{ Perseverative behavior } \\
\hline \multicolumn{3}{|l|}{ Abnormal visual behaviour for age } \\
\hline \multicolumn{3}{|l|}{ Behavioral disorders } \\
\hline \multicolumn{3}{|l|}{ Hyperactive behavior } \\
\hline \multicolumn{3}{|l|}{ Abnormal emotion/affect behaviour } \\
\hline \multicolumn{3}{|l|}{ Addictive behavior } \\
\hline \multicolumn{3}{|l|}{ Violent behavior } \\
\hline Aggressive behavior & & \\
\hline
\end{tabular}

Figure 3. Example of downloadable Phenotypr output.

Thank you for submitting your survey!

Following are your HPO Terms

\begin{tabular}{llr} 
Symptom & HPO Term & HPO \# \\
\hline Hyperactive behavior & Hyperactivity & HP:0000752 \\
Headaches & Headache & HP:0002315 \\
Vision issue & Abnormality of vision & HP:00001504 \\
Growth delay & Growth delay & HP:0002360
\end{tabular}

\section{Data Collection}

Study administrators added participants along with their unique identification number and email address into a secure REDCap database. Participants were then sent an email that contained an invitation and unique link to fill out Phenotypr. The Phenotypr survey was administered via an external web interface and took participants approximately 10 to 15 minutes to complete (Figures 1-3). Each user was assigned a unique token 
that was carried through to make sure the data were tied to that user. Survey data entered into Phenotypr by participants were temporarily saved in a local Boston Children's Hospital database.

Two scripts (jobs) were run once every day. The first script imported the newly entered participant information from Boston Children's Hospital's internal instance of REDCap and synced it into the local database. The second script exported the survey data (that was filled in by the participant) from the local database into the REDCap instance. The REDCap database included all of the questions that were asked on the external web form. Thus, REDCap provided a secure way to analyze data, create participants, send reminder emails, and manage users.

Deidentified data were exported into an Excel spreadsheet for further analysis and sharing.

\section{Results}

Nineteen participants enrolled in the study and completed the survey. The caregiver, parent, or legal guardian filled out the Phenotypr survey in 15 of 19 cases. In the other four cases, it was not reported whether the respondent filled out the survey on behalf of themselves or as a caregiver, parent, or legal guardian (Table 1). Table 1 lists the phenotypic characteristics of our cohort as reported in Phenotypr (see Multimedia Appendix 1 for a complete table of phenotypic features).

In order to assess the initial accuracy of the Phenotypr tool, a comparison was conducted between the $16 \mathrm{p} 13.11$ microduplication syndrome phenotypes that were present in our cohort and those in a recent case report with a larger sample size [4] (Table 2). Moreover, we compared our cohort to all previously published cases of dup16p13.11 CNV and discovered several underrepresented phenotypes, which are summarized in Table $3[1,3-5,19]$.

At least one of the phenotypes mentioned in previous publications, such as delayed speech, learning/intellectual disability, ASD, sleep disorder, and feeding difficulties [1-5], was reported by a majority of the Phenotypr participants (10/19 [53\%] cases with at least one phenotype; Table 1). Meanwhile, aggression, which has not been widely reported in previous $16 \mathrm{p} 13.11$ microduplication literature, was reported by three families (Table 3 ).

Additionally, 4 out of 19 (21\%) cases mentioned anxiety or anxiety-related behaviors, which is higher than the prevalence of anxiety reported by the Centers for Disease Control and Prevention (approximately 7\% in US children aged 3-17 years) [20].

Finally, 5 out of 19 (26\%) participants reported immune- and/or autoimmune-related disorders, including severe T-cell immunodeficiency in one patient and "autoimmune encephalopathy and corresponding antibody positivity" in another. Three cases reported asthma, a broadly recognized autoimmune disease, with one individual also having co-occurring hypothyroidism [21]. 
Table 1. Selected phenotypic features in 19 cases of 16p13.11 microduplication syndrome.

\begin{tabular}{|c|c|c|c|c|c|c|c|c|c|c|c|c|c|c|c|c|c|c|c|}
\hline \multirow[t]{2}{*}{ Characteristic } & \multicolumn{19}{|c|}{ Presented cases (patient numbers) } \\
\hline & 1 & 2 & 3 & 4 & 5 & 6 & 7 & 8 & 9 & 10 & 11 & 12 & 13 & 14 & 15 & 16 & 17 & 18 & 19 \\
\hline Age (years) & 10 & 3 & 8 & 2 & 14 & 12 & 14 & 5 & $<1$ & 7 & 6 & $N A^{a}$ & NA & 4 & 18 & NA & 3 & 9 & NA \\
\hline
\end{tabular}

\section{Growth}

Growth abnormality

Muscle weakness

Tall stature

\section{Development}

Delayed speech

Developmental regression

Intellectual disability

Mild global DD ${ }^{\mathrm{d}}$

\section{Neurological and mental}

Specific learning disability

Dyslexia

Cognitive impairment

Hypotonia

Poor fine motor coordination

Tics

Spasticity

Dysarthria

Anxiety

Depression

$\mathrm{ODD}^{\mathrm{e}}$

$\operatorname{ADHD}^{\mathrm{f}}$

Seizure

$\mathrm{ASD}^{\mathrm{g}}$ /autistic behavior

Sleep disturbance

Parasomnia

\section{Behavior}

Behavioral abnormality

Impulsiveness or violence

Aggression

Abnormal eating

Self-mutilation

Abnormal fear/anxiety

DMDD $^{\mathrm{h}}$

\section{Sensory}

Sensory impairment

Hearing impairment

Tinnitus

Astigmatism

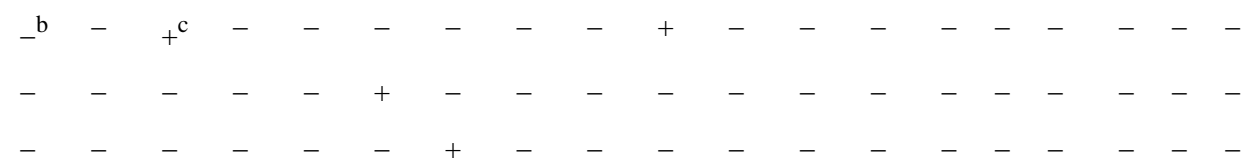


Characteristic Presented cases (patient numbers)

\begin{tabular}{|c|c|c|c|c|c|c|c|c|c|c|c|c|c|c|c|c|c|c|c|}
\hline & 1 & 2 & 3 & 4 & 5 & 6 & 7 & 8 & 9 & 10 & 11 & 12 & 13 & 14 & 15 & 16 & 17 & 18 & 19 \\
\hline \multicolumn{20}{|l|}{ Immunity } \\
\hline Abnormality of the immune system & - & - & + & - & - & - & - & - & - & - & - & - & - & - & - & - & - & - & - \\
\hline Severe T-cell immunodeficiency & - & - & + & - & - & - & - & - & - & - & - & - & - & - & - & - & - & - & - \\
\hline Autoimmune antibody positivity & - & - & - & - & - & + & - & - & - & - & - & - & - & - & - & - & - & - & - \\
\hline Autoimmune encephalopathy & - & - & - & - & - & + & - & - & - & - & - & - & - & - & - & - & - & - & - \\
\hline \multicolumn{20}{|l|}{ Cardiac and respiratory } \\
\hline Arrhythmia & - & - & - & - & - & - & - & - & - & - & - & - & - & - & + & - & - & - & - \\
\hline Bradycardia & - & - & + & - & - & - & - & - & - & - & - & - & - & - & - & - & - & - & - \\
\hline Asthma & - & - & - & - & - & - & - & - & - & - & - & - & - & - & + & - & + & - & + \\
\hline Chronic lung disease & - & - & - & + & - & - & - & - & - & - & - & - & - & - & - & - & - & - & - \\
\hline Neonatal respiratory distress & - & - & - & - & - & - & - & - & - & + & - & - & - & - & - & - & - & - & - \\
\hline Breathing dysregulation & - & - & - & - & - & - & - & - & - & - & - & - & - & + & - & - & - & - & - \\
\hline \multicolumn{20}{|l|}{ Feeding difficulties } \\
\hline Gastrostomy tube feeding in infancy & - & - & - & + & - & - & - & - & - & - & - & - & - & - & - & - & - & - & - \\
\hline Dysphagia & - & - & - & - & - & - & - & - & - & + & - & - & - & - & - & - & - & - & - \\
\hline Feeding difficulties & - & - & - & + & - & - & - & - & - & + & - & - & - & - & - & - & - & - & - \\
\hline
\end{tabular}

${ }^{\mathrm{a}} \mathrm{N} / \mathrm{A}$ : not applicable.

${ }^{\mathrm{b}}$ Feature absent or undisclosed.

${ }^{\mathrm{c}}$ Feature present.

${ }^{\mathrm{d}} \mathrm{DD}$ : developmental delay.

${ }^{\mathrm{e} O D D}$ : oppositional defiant disorder.

${ }^{\mathrm{f}}$ ADHD: attention-deficit/hyperactivity disorder.

${ }^{\mathrm{g}}$ ASD: autism spectrum disorder.

${ }^{\mathrm{h}}$ DMDD: disruptive mood dysregulation disorder. 
Table 2. Comparison of the self-phenotyping cohort with the published cohort in the study by Allach El Khattabi et al [4].

\begin{tabular}{|c|c|c|}
\hline Feature & Cases in the study by Allach El Khattabi et al [4] $(\mathrm{N}=45)$ & Presented cases $(\mathrm{N}=19)$ \\
\hline Hypotonia & $5 / 45$ & $3 / 19$ \\
\hline Feeding difficulties & $5 / 45$ & $2 / 19$ \\
\hline \multicolumn{3}{|l|}{ Neurodevelopmental features } \\
\hline Developmental delay ${ }^{\mathrm{a}}$ & $32 / 45$ & $3 / 19$ \\
\hline Motor delay ${ }^{\mathrm{b}}$ & $19 / 45$ & $2 / 19$ \\
\hline Speech delay & $35 / 45$ & $3 / 19$ \\
\hline Learning disabilities & $30 / 45$ & $2 / 19$ \\
\hline $\mathrm{ASD}^{\mathrm{c}}$ & $24 / 45$ & $4 / 19$ \\
\hline Aggression & ${ }^{\mathrm{d}}$ & $3 / 19$ \\
\hline Anxiety & - & $4 / 19$ \\
\hline Seizures & $10 / 45$ & $3 / 19$ \\
\hline Sleep disorders ${ }^{\mathrm{e}}$ & $8 / 45$ & $4 / 19$ \\
\hline \multicolumn{3}{|l|}{ Craniofacial features } \\
\hline Microcephaly & $1 / 23$ & $1 / 19$ \\
\hline \multicolumn{3}{|l|}{ Abnormal extremities } \\
\hline \multicolumn{3}{|l|}{ Hands } \\
\hline Long fingers & $1 / 22$ & $1 / 19$ \\
\hline \multicolumn{3}{|l|}{ Eyes } \\
\hline Strabismus & $6 / 45$ & $1 / 19$ \\
\hline Myopia & $4 / 45$ & $1 / 19$ \\
\hline Amblyopia & $1 / 23$ & $1 / 19$ \\
\hline Nystagmus & $1 / 22$ & $1 / 19$ \\
\hline \multicolumn{3}{|l|}{ Immunological disorders } \\
\hline Immunodeficiency and autoimmune diseases & - & $2 / 19$ \\
\hline \multicolumn{3}{|l|}{ Others } \\
\hline Asthma & - & $3 / 19$ \\
\hline Hypothyroidism & - & $1 / 19$ \\
\hline Umbilical hernia & $1 / 22$ & $1 / 19$ \\
\hline Hearing loss ${ }^{\mathrm{f}}$ & $1 / 23$ & $3 / 19$ \\
\hline Abnormality of the male genitalia & 2 testicular ectopia and 1 cryptorchidism & $1 / 19$ \\
\hline
\end{tabular}

ancluding "developmental regression" and "mild global developmental delay."

b Corresponding to "poor fine motor coordination."

${ }^{c}$ ASD: autism spectrum disorder.

${ }^{\mathrm{d}}$ Not available.

eIncluding "sleep disturbance" and "parasomnia."

f Corresponding to "hearing impairment." 
Table 3. Comparison of the self-phenotyping cohort with published case reports for anxiety, aggression, asthma, and immunological disorder phenotypes.

\begin{tabular}{|c|c|c|c|c|c|c|}
\hline Phenotype & $\begin{array}{l}\text { Cases in the } \\
\text { study by Hannes } \\
\text { et al [5] }(\mathrm{N}=5)\end{array}$ & $\begin{array}{l}\text { Cases in the study } \\
\text { by Ramalingam et } \\
\text { al [1] }(\mathrm{N}=8)\end{array}$ & $\begin{array}{l}\text { Cases in the study } \\
\text { by Nagamani et al } \\
{[3](N=10)}\end{array}$ & $\begin{array}{l}\text { Cases in the } \\
\text { study by Loureiro } \\
\text { et al [19] }(\mathrm{N}=4)\end{array}$ & $\begin{array}{l}\text { Cases in the study } \\
\text { by Allach El Khat- } \\
\text { tabi et al [4] }(\mathrm{N}=45)\end{array}$ & $\begin{array}{l}\text { Cases in this } \\
\text { study }(\mathrm{N}=19)\end{array}$ \\
\hline Anxiety & $-^{\mathrm{a}}$ & $1 / 8^{\mathrm{b}}$ & - & $1 / 4^{\mathrm{c}}$ & - & $4 / 19$ \\
\hline Aggression & $1 / 5$ & - & $1 / 10$ & - & - & $3 / 19$ \\
\hline Asthma & - & - & - & - & - & $3 / 19$ \\
\hline Immunological disorders $^{\mathrm{d}}$ & - & - & - & - & - & $2 / 19$ \\
\hline
\end{tabular}

${ }^{\mathrm{a}}$ Not available.

${ }^{\mathrm{b}}$ Co-occurring with autism spectrum disorder and attention-deficit/hyperactivity disorder.

${ }^{\mathrm{c}}$ Co-occurring with autism spectrum disorder and hyperactivity.

dIncluding "abnormality of the immune system," “severe T-cell immunodeficiency," "autoimmune antibody positivity," and "autoimmune encephalopathy."

\section{Discussion}

\section{Principal Findings}

This cohort of $1916 \mathrm{p} 13.11$ microduplication cases expands the knowledge of an increasingly concerning syndrome. It supports the role of many clinical features that have been previously described, including growth and behavioral disturbances, seizures, and a spectrum of neurological characteristics (Table 1). Further, the frequency of anxiety and aggression in the cohort illustrates the potential utility of self-phenotyping and nonhypothesis-driven phenotyping tools as informative data sources. The amount of immune disorders reported is also an interesting finding worthy of further investigation. The incidence rate of asthma in the cohort $(3 / 19,16 \%)$ was higher than that in published reports from the Centers for Disease Control and Prevention in 2018 (about 1/13, 8\%) [22]. Taken together, these results imply the possibility of a broader impact of the genotype on the immune system.

\section{Limitations}

A limitation of this study is ascertainment bias. The participants were located in geographic areas where they had increased access to clinical microarray technology and formal medical diagnosis, and presented with severe enough phenotypes that the families had sought joining an online registry to participate in research; therefore, it is possible that this cohort is more severely impacted than 16p13.11 microduplication cases in the general population. Patients and families dealing with unique presentations may also be more incentivized to participate in research and use an internet self-phenotyping tool. That said, published studies may also have had similar biases, as they were recruiting participants with otherwise unexplained phenotypes, who went on to have chromosomal microarray testing, thus limiting our assessment on the presence of normal variation. Another limitation comes from the fact that for four out of 19 respondents, the individuals did not indicate whether they were filling out the survey as an individual with $16 \mathrm{p} 13.11$ microduplication syndrome or as a caregiver. This can add variability in the responses and cause information bias from surrogate interviews [23].

\section{Comparison With Prior Work on 16p13.11 Microduplication}

New phenotypes associated with the dup16p13.11 CNV have been continuously discovered and reported since the syndrome first came to light in 2007 when Ullmann et al initially identified the 16p13.11 microduplication and believed it predisposed patients to ASD and intellectual disability [2]. Subsequently, further studies have indicated that the 16p13.11 microduplication is likely to be involved with a wide spectrum of neurodevelopmental disorders [1,24-27]. We hereby identified two neuropsychiatric disorders, anxiety and aggression, as supplementary evidence to the underrepresented cases in prior reports, and we underline a probable high occurrence of these two phenotypes in patients with dup16p13.11. As shown in Table 3, only two cases of anxiety have been previously reported; one by Ramalingam et al (1/8 patients) [1] in 2011 and another by Loureiro et al (1/4 patients) [19] in 2017. Although one case was inherited and the other occurred de novo, both aforementioned cases were associated with ASD or ADHD, which aligns with literature that anxiety is a common condition in patients with ADHD and ASD [28,29]. In our cases, however, just one individual with anxiety had co-occurring ASD, whereas the remaining three cases of anxiety appeared independently. Meanwhile, aggression was also noted in three family reports, and it has gone largely unreported since Hannes et al first described a case of aggression in a patient with dup16p13.11 in 2009 [5], and another case was reported in the study by Nagamani et al in 2011 [3]. Furthermore, a potential correlation between 16p13.11 microduplication and a range of immunological disorders, specifically autoimmune conditions, was uncovered in multiple individuals in our cohort.

Aggressive behavior is one of the most common reasons for mental health referrals in children and adolescents [30-32], and can co-occur with a broad array of psychiatric and neurological illnesses, including ASD, intellectual disability, ADHD, conduct disorder, oppositional defiant disorder, disruptive mood dysregulation disorder, schizophrenia, epilepsy, anxiety, depression, and sleep disorders [33,34]. While impulsive aggression may not indicate any specific disorder, it is an important marker of severity for many psychiatric diseases [35]. For example, aggression level may affect the decision to initiate or increase medication dosage in pediatric ADHD treatment [36]. Regardless of the controversy over whether to consider 
impulsive aggression as an independent categorical diagnosis like a disorder [37] or a measurable symptom secondary to some other diagnostic entity like fever or pain [32,38], it can greatly impact an individual's development and health, or even lead to high economic and medical burden for families and communities [39-41]. This paper does not aim to address the dispute over the clinical perception of aggression by joining any side or to unduly correlate 16p13.11 microduplication with the aggression phenotype. Instead, we hope to draw more attention to the repeatedly mentioned and thus important phenotypes that are self-reported by the patient families and call for more focus on related research and therapeutics.

The potential connection between neuropsychiatric disorders and autoimmunity/immunological dysfunction has received growing interest over the past decades. For instance, a nationwide population-based prospective cohort study in Denmark used a longitudinal registry to find that autoimmune diseases and infection raised the risk for subsequent mood disorder [42]. Another well-covered example is the bidirectional relationship between psychosis and autoimmune disorders [43], specifically schizophrenia and celiac disease, between which positive correlations have been suggested through studies of epidemiology, genetics, and immunology [44,45]. Notably, the discovery of autoimmune encephalitis and the disruptive autoantibody mechanisms behind it provided more direct proof of etiological linkage [46-49]. Autoimmune encephalitis is an abrupt inflammatory brain disease characterized by a variety of neuropsychiatric symptoms, such as cognitive and behavioral alterations, seizures, anxiety, and sleep disturbances [50,51], and responds to immunotherapy treatment in many cases [52,53]. Among all the possible causative autoantibodies, one of the most discussed is the N-methyl-D-aspartate receptor (NMDAR) antibody. The NMDAR antibody targets a certain subunit of NMDAR, a synaptic and neuronal cell membrane protein, and has been revealed to play a role in the development and progression of schizophrenia [47,54-57] and ASD [58-61] Given the long-lasting belief that ASD is largely genetic [62-66], our finding of several individuals with dup16p13.11 CNV who have immunity-related diseases and neuropsychiatric symptoms, especially a case with both ASD and autoimmune encephalopathy plus corresponding antibody positivity, supports the medical field's current views and may influence future studies that seek to understand genetic origin.

It is worth noting that new associated phenotypes may emerge even for established genetic diseases as more scientific research is conducted and the demographic profiles of patient populations shift. For example, though the first case of Down syndrome was reported in the 19th century, it was not until the last two decades that individuals with Down syndrome were identified as having an increasing risk of early-onset Alzheimer disease as they age; many individuals with Down syndrome start to develop Alzheimer disease pathology in their 30s and approximately two-thirds have dementia by the age of 60 years $[67,68]$. Due to advancements in health care and social support, the life expectancy of the Down syndrome population has greatly improved, with the average age of death in developed countries now approaching 60 years [69]. A similar increase in knowledge has occurred regarding Turner syndrome, which was first described in the 1930s and is one of the most common genetic disorders [70,71]. Some patients with Turner syndrome who carried a mosaic 46, XY karyotype or an abnormal Y chromosome were recently found to have a higher risk of developing gonadoblastoma and other gonadal tumors owing to the widespread use and easy availability of polymerase chain reaction technology $[7,72]$. For genetic diseases with variable presentations and complex genotypes, such as Down syndrome and Turner syndrome, it may be too early to announce that all phenotypes have been exhaustively discovered and included.

We do not claim that Phenotypr is a substitute for clinician phenotyping, and it is unlikely that participants will be able to describe some of the highly technical aspects of their disorders in clinical terminology. Therefore, we do not consider the underreporting of some phenotypes in Phenotypr to be notable. In contrast, phenotypes that were repeatedly mentioned by participants but have not been well discussed in the literature are worthy of further investigation. It is possible that patients and families are not mentioning these phenotypes in clinic visits or that their existing concerns are not being fully understood.

\section{Conclusions}

In this study, we utilized the Phenotypr tool to collect self-phenotyping data from 19 16p13.11 microduplication syndrome cases, with the aim of identifying underrepresented phenotypes in the current scientific literature. A number of phenotypes were highlighted, including aggression, anxiety, and a range of immunological disorders. In addition to the typically recognized phenotypes, dup16p13.11 CNV showed a stronger predisposition to aggression and anxiety compared to previously reported cases, as both phenotypes were mentioned by multiple Phenotypr participant families (4/19, 21\%). Moreover, we found that three out of four cases with anxiety did not have co-occurring ASD or ADHD, which differed from two other published cases $[1,28]$. An interesting case that involved ASD and autoimmune encephalopathy with corresponding antibody positivity was also identified using Phenotypr. These findings illustrate some important hypotheses. First, aggression and anxiety may be more common than previously understood in 16p13.11 microduplication cases. Second, anxiety may appear independently as a result of dup16p13.11 CNV instead of being accompanied with ASD or ADHD. Third, immune and autoimmune disorders might be phenotypes of 16p13.11 microduplication, and dup16p13.11 $\mathrm{CNV}$ might play a genetic role in the association between autoimmune encephalopathy and ASD. Fourth, in consideration of the incomplete penetrance and varied expression of this syndrome in a broad spectrum of neuropsychiatric disorders, patients and their clinicians should be aware of all possible phenotypes to ensure that treatment is as effective as possible. Fifth, HPO and layperson HPO profiles acquired through patient self-phenotyping can serve as a valuable data source for the exploration of underreported phenotypes in the scientific literature, especially for rare disorders with variable presentations.

Future work will apply Phenotypr to additional 16p13.11 microduplication cases and correlate phenotypic results to the size of the duplicated interval and the genes involved. We also 
look forward to adopting Phenotypr as a complementary data source in other genetic cohort studies of rare diseases.

\section{Acknowledgments}

We thank the patients and families who participated in this study. This work was supported by the Patient-Centered Outcomes Research Institute (PCORI) (grant \#HSRP20181624), Tommy Fuss Fund, Robin and Jonathan Klein Family, and National Institutes of Health U54 (HD090255).

\section{Conflicts of Interest}

In the past 3 years, JGH has received grant support from the Tommy Fuss Fund. He is the founding head of the Scientific Advisory Board and has equity in Mightier/Neuro'motion, Inc, a company working on emotional regulation training tools. He has been a consultant to Neurocrine and Alkermes pharmaceutical companies. Author MH is the cofounder of Pryzm Health. The other authors have no conflicts to declare.

\section{Multimedia Appendix 1}

Selected phenotypic features in 19 cases of $16 \mathrm{p} 13.11$ microduplication syndrome.

[DOCX File , 56 KB-Multimedia Appendix 1]

\section{References}

1. Ramalingam A, Zhou X, Fiedler SD, Brawner SJ, Joyce JM, Liu H, et al. 16p13.11 duplication is a risk factor for a wide spectrum of neuropsychiatric disorders. J Hum Genet 2011 Jul;56(7):541-544 [FREE Full text] [doi: 10.1038/jhg.2011.42] [Medline: 21614007]

2. Ullmann R, Turner G, Kirchhoff M, Chen W, Tonge B, Rosenberg C, et al. Array CGH identifies reciprocal 16p13.1 duplications and deletions that predispose to autism and/or mental retardation. Hum Mutat 2007 Jul;28(7):674-682. [doi: 10.1002/humu.20546] [Medline: 17480035]

3. Nagamani SCS, Erez A, Bader P, Lalani SR, Scott DA, Scaglia F, et al. Phenotypic manifestations of copy number variation in chromosome 16p13.11. Eur J Hum Genet 2011 Mar;19(3):280-286 [FREE Full text] [doi: 10.1038/ejhg.2010.184] [Medline: 21150890]

4. Allach El Khattabi L, Heide S, Caberg J, Andrieux J, Doco Fenzy M, Vincent-Delorme C, et al. 16p13.11 microduplication in 45 new patients: refined clinical significance and genotype-phenotype correlations. J Med Genet 2020 May;57(5):301-307. [doi: 10.1136/jmedgenet-2018-105389] [Medline: $\underline{\text { 30287593] }}$

5. Hannes FD, Sharp AJ, Mefford HC, de Ravel T, Ruivenkamp CA, Breuning MH, et al. Recurrent reciprocal deletions and duplications of 16p13.11: the deletion is a risk factor for MR/MCA while the duplication may be a rare benign variant. J Med Genet 2009 Apr;46(4):223-232 [FREE Full text] [doi: 10.1136/jmg.2007.055202] [Medline: 18550696]

6. Brownstein CA, Kleiman RJ, Engle EC, Towne MC, D'Angelo EJ, Yu TW, et al. Overlapping 16p13.11 deletion and gain of copies variations associated with childhood onset psychosis include genes with mechanistic implications for autism associated pathways: Two case reports. Am J Med Genet A 2016 May;170A(5):1165-1173 [FREE Full text] [doi: 10.1002/ajmg.a.37595] [Medline: 26887912]

7. Tropeano M, Andrieux J, Collier DA. Clinical utility gene card for: 16p13.11 microdeletion syndrome. Eur J Hum Genet 2014 May;22(5):1-4 [FREE Full text] [doi: 10.1038/ejhg.2013.230] [Medline: 24105370]

8. Bradshaw NJ, Ukkola-Vuoti L, Pankakoski M, Zheutlin AB, Ortega-Alonso A, Torniainen-Holm M, et al. The genomic locus can affect treatment of psychiatric illness through gene expression changes related to microRNA-484. Open Biol 2017 Nov;7(11) [FREE Full text] [doi: 10.1098/rsob.170153] [Medline: 29142105]

9. Savatt JM, Azzariti DR, Faucett WA, Harrison S, Hart J, Kattman B, et al. ClinGen's GenomeConnect registry enables patient-centered data sharing. Hum Mutat 2018 Nov;39(11):1668-1676 [FREE Full text] [doi: 10.1002/humu.23633] [Medline: $\underline{30311371]}$

10. Kirkpatrick BE, Riggs ER, Azzariti DR, Miller VR, Ledbetter DH, Miller DT, ClinGen Resource. GenomeConnect: matchmaking between patients, clinical laboratories, and researchers to improve genomic knowledge. Hum Mutat 2015 Oct;36(10):974-978 [FREE Full text] [doi: 10.1002/humu.22838] [Medline: 26178529]

11. Köhler S, Carmody L, Vasilevsky N, Jacobsen JOB, Danis D, Gourdine J, et al. Expansion of the Human Phenotype Ontology (HPO) knowledge base and resources. Nucleic Acids Res 2019 Jan 08;47(D1):D1018-D1027 [FREE Full text] [doi: 10.1093/nar/gky1105] [Medline: 30476213]

12. Köhler S, Doelken SC, Mungall CJ, Bauer S, Firth HV, Bailleul-Forestier I, et al. The Human Phenotype Ontology project: linking molecular biology and disease through phenotype data. Nucleic Acids Res 2014 Jan;42(Database issue):D966-D974 [FREE Full text] [doi: 10.1093/nar/gkt1026] [Medline: 24217912]

13. Robinson PN, Köhler S, Bauer S, Seelow D, Horn D, Mundlos S. The Human Phenotype Ontology: a tool for annotating and analyzing human hereditary disease. Am J Hum Genet 2008 Nov;83(5):610-615 [FREE Full text] [doi: 10.1016/j.ajhg.2008.09.017] [Medline: 18950739] 
14. Vasilevsky NA, Foster ED, Engelstad ME, Carmody L, Might M, Chambers C, et al. Plain-language medical vocabulary for precision diagnosis. Nat Genet 2018 Apr;50(4):474-476 [FREE Full text] [doi: 10.1038/s41588-018-0096-x] [Medline: 29632381]

15. Phenotypr. Boston Children's Hospital. 2017. URL: http://www.phenotypr.com [accessed 2020-07-28]

16. Harris PA, Taylor R, Thielke R, Payne J, Gonzalez N, Conde JG. Research electronic data capture (REDCap)--a metadata-driven methodology and workflow process for providing translational research informatics support. J Biomed Inform 2009 Apr;42(2):377-381 [FREE Full text] [doi: 10.1016/j.jbi.2008.08.010] [Medline: 18929686]

17. Solr. The Apache Software Foundation. URL: https://lucene.apache.org/solr/ [accessed 2020-07-28]

18. Vue.js. 2020. URL: https://vuejs.org/ [accessed 2020-07-28]

19. Loureiro S, Almeida J, Café C, Conceição I, Mouga S, Beleza A, et al. Copy number variations in chromosome 16p13.11-The neurodevelopmental clinical spectrum. Current Pediatric Research 2017 Jan;21(1):116-129 [FREE Full text]

20. Data and Statistics on Children's Mental Health. Centers for Disease Control and Prevention. 2019 Jun 15. URL: https:/ /www.cdc.gov/childrensmentalhealth/data.html [accessed 2020-07-28]

21. Amino N. 4 Autoimmunity and hypothyroidism. Baillière's Clinical Endocrinology and Metabolism 1988 Aug;2(3):591-617. [doi: $\underline{10.1016 / \mathrm{s} 0950-351 \times(88) 80055-7]}$ [Medline: $\underline{\text { 3066320] }}$

22. Most Recent National Asthma Data. Centers for Disease Control and Prevention. 2020. URL: https://www.cdc.gov/asthma/ most recent national asthma data.htm [accessed 2020-08-31]

23. Aitken JF, Green A, MacLennan R, Jackman L, Martin NG. Comparability of surrogate and self-reported information on melanoma risk factors. Br J Cancer 1993 May;67(5):1036-1041 [FREE Full text] [doi: 10.1038/bjc.1993.190] [Medline: $\underline{8494696]}$

24. Mefford HC, Cooper GM, Zerr T, Smith JD, Baker C, Shafer N, et al. A method for rapid, targeted CNV genotyping identifies rare variants associated with neurocognitive disease. Genome Res 2009 Sep;19(9):1579-1585 [FREE Full text] [doi: 10.1101/gr.094987.109] [Medline: 19506092]

25. Mefford HC, Muhle H, Ostertag P, von Spiczak S, Buysse K, Baker C, et al. Genome-wide copy number variation in epilepsy: novel susceptibility loci in idiopathic generalized and focal epilepsies. PLoS Genet 2010 May 20;6(5):e1000962 [FREE Full text] [doi: 10.1371/journal.pgen.1000962] [Medline: 20502679]

26. Williams NM, Zaharieva I, Martin A, Langley K, Mantripragada K, Fossdal R, et al. Rare chromosomal deletions and duplications in attention-deficit hyperactivity disorder: a genome-wide analysis. The Lancet 2010 Oct 23;376(9750):1401-1408 [FREE Full text] [doi: 10.1016/S0140-6736(10)61109-9] [Medline: 20888040]

27. Kuang S, Guo D, Prakash SK, McDonald MN, Johnson RJ, Wang M, GenTAC Investigators. Recurrent chromosome 16p13.1 duplications are a risk factor for aortic dissections. PLoS Genet 2011 Jun;7(6):e1002118 [FREE Full text] [doi: 10.1371/journal.pgen.1002118] [Medline: 21698135]

28. Schatz DB, Rostain AL. ADHD with comorbid anxiety: a review of the current literature. J Atten Disord 2006 Nov;10(2):141-149. [doi: 10.1177/1087054706286698] [Medline: 17085624]

29. South M, Rodgers J, Van Hecke A. Anxiety and ASD: Current Progress and Ongoing Challenges. J Autism Dev Disord 2017 Dec;47(12):3679-3681. [doi: 10.1007/s10803-017-3322-y] [Medline: 28988366]

30. Connor DF. Aggression and Antisocial Behavior in Children and Adolescents: Research and Treatment. New York, NY: Guilford Press; 2004.

31. Steiner H, Saxena K, Chang K. Psychopharmacologic strategies for the treatment of aggression in juveniles. CNS Spectr 2003 Apr;8(4):298-308. [doi: 10.1017/s1092852900018514] [Medline: 12679744]

32. Jensen PS, Youngstrom EA, Steiner H, Findling RL, Meyer RE, Malone RP, et al. Consensus report on impulsive aggression as a symptom across diagnostic categories in child psychiatry: implications for medication studies. J Am Acad Child Adolesc Psychiatry 2007 Mar;46(3):309-322. [doi: 10.1097/chi.0b013e31802f1454] [Medline: 17314717]

33. Connor DF, Newcorn JH, Saylor KE, Amann BH, Scahill L, Robb AS, et al. Maladaptive Aggression: With a Focus on Impulsive Aggression in Children and Adolescents. J Child Adolesc Psychopharmacol 2019 Oct;29(8):576-591 [FREE Full text] [doi: 10.1089/cap.2019.0039] [Medline: 31453715]

34. Magalotti S, Neudecker M, Zaraa S, McVoy M. Understanding Chronic Aggression and Its Treatment in Children and Adolescents. Curr Psychiatry Rep 2019 Nov 18;21(12):123 [FREE Full text] [doi: 10.1007/s11920-019-1105-1] [Medline: 31741142]

35. Connor DF, McLaughlin TJ. Aggression and diagnosis in psychiatrically referred children. Child Psychiatry Hum Dev 2006;37(1):1-14. [doi: 10.1007/s10578-006-0015-8] [Medline: 16779500]

36. Connor DF, Doerfler LA. ADHD with comorbid oppositional defiant disorder or conduct disorder: discrete or nondistinct disruptive behavior disorders? J Atten Disord 2008 Sep;12(2):126-134. [doi: 10.1177/1087054707308486] [Medline: 17934178]

37. Coccaro EF, Fanning JR, Phan KL, Lee R. Serotonin and impulsive aggression. CNS Spectr 2015 Jun;20(3):295-302. [doi: 10.1017/S1092852915000310] [Medline: 25997605]

38. Raine A, Dodge K, Loeber R, Gatzke-Kopp L, Lynam D, Reynolds C, et al. The Reactive-Proactive Aggression Questionnaire: Differential Correlates of Reactive and Proactive Aggression in Adolescent Boys. Aggress Behav 2006 Apr 01;32(2):159-171 [FREE Full text] [doi: 10.1002/ab.20115] [Medline: 20798781] 
39. Broidy LM, Nagin DS, Tremblay RE, Bates JE, Brame B, Dodge KA, et al. Developmental trajectories of childhood disruptive behaviors and adolescent delinquency: A six-site, cross-national study. Developmental Psychology 2003 Mar;39(2):222-245 [FREE Full text] [doi: 10.1037//0012-1649.39.2.222] [Medline: 12661883]

40. Raaijmakers MA, Posthumus JA, van Hout BA, van Engeland H, Matthys W. Cross-sectional study into the costs and impact on family functioning of 4-year-old children with aggressive behavior. Prev Sci 2011 Jun;12(2):192-200 [FREE Full text] [doi: 10.1007/s11121-011-0204-y] [Medline: 21369841]

41. Hendricks K, Liu J. Childbearing depression and childhood aggression: literature review. MCN Am J Matern Child Nurs 2012;37(4):253-261 [FREE Full text] [doi: 10.1097/NMC.0b013e3182482c5e] [Medline: 22739482]

42. Benros ME, Waltoft BL, Nordentoft M, Ostergaard SD, Eaton WW, Krogh J, et al. Autoimmune diseases and severe infections as risk factors for mood disorders: a nationwide study. JAMA Psychiatry 2013 Aug;70(8):812-820. [doi: 10.1001/jamapsychiatry.2013.1111] [Medline: 23760347]

43. Benros ME, Nielsen PR, Nordentoft M, Eaton WW, Dalton SO, Mortensen PB. Autoimmune diseases and severe infections as risk factors for schizophrenia: a 30-year population-based register study. Am J Psychiatry 2011 Dec;168(12):1303-1310. [doi: 10.1176/appi.ajp.2011.11030516] [Medline: 22193673]

44. Benros ME, Eaton WW, Mortensen PB. The epidemiologic evidence linking autoimmune diseases and psychosis. Biol Psychiatry 2014 Feb 15;75(4):300-306. [doi: 10.1016/j.biopsych.2013.09.023] [Medline: 24199668]

45. Jeppesen R, Benros ME. Autoimmune Diseases and Psychotic Disorders. Front Psychiatry 2019 Mar 20;10:131 [FREE Full text] [doi: 10.3389/fpsyt.2019.00131] [Medline: $\underline{\text { 30949074] }}$

46. Dalmau J, Tüzün E, Wu H, Masjuan J, Rossi JE, Voloschin A, et al. Paraneoplastic anti-N-methyl-D-aspartate receptor encephalitis associated with ovarian teratoma. Ann Neurol 2007 Jan;61(1):25-36 [FREE Full text] [doi: 10.1002/ana.21050] [Medline: 17262855]

47. Kayser MS, Dalmau J. The emerging link between autoimmune disorders and neuropsychiatric disease. J Neuropsychiatry Clin Neurosci 2011;23(1):90-97 [FREE Full text] [doi: 10.1176/jnp.23.1.jnp90] [Medline: 21304144]

48. Al-Diwani AAJ, Pollak TA, Irani SR, Lennox BR. Psychosis: an autoimmune disease? Immunology 2017 Nov;152(3):388-401 [FREE Full text] [doi: 10.1111/imm.12795] [Medline: 28704576]

49. Mané-Damas M, Hoffmann C, Zong S, Tan A, Molenaar PC, Losen M, et al. Autoimmunity in psychotic disorders. Where we stand, challenges and opportunities. Autoimmun Rev 2019 Sep;18(9):102348 [FREE Full text] [doi: 10.1016/j.autrev.2019.102348] [Medline: 31323365]

50. Dalmau J, Gleichman AJ, Hughes EG, Rossi JE, Peng X, Lai M, et al. Anti-NMDA-receptor encephalitis: case series and analysis of the effects of antibodies. The Lancet Neurology 2008 Dec;7(12):1091-1098 [FREE Full text] [doi: 10.1016/S1474-4422(08)70224-2] [Medline: 18851928]

51. Herken J, Prüss H. Red Flags: Clinical Signs for Identifying Autoimmune Encephalitis in Psychiatric Patients. Front Psychiatry 2017;8:25 [FREE Full text] [doi: 10.3389/fpsyt.2017.00025] [Medline: 28261116]

52. Gotkine M, Ben-Hur T, Vincent A, Vaknin-Dembinsky A. Limbic encephalitis presenting as a post-partum psychiatric condition. J Neurol Sci 2011 Sep 15;308(1-2):152-154. [doi: 10.1016/j.jns.2011.06.017] [Medline: 21705029]

53. Kayser MS, Titulaer MJ, Gresa-Arribas N, Dalmau J. Frequency and characteristics of isolated psychiatric episodes in anti-N-methyl-d-aspartate receptor encephalitis. JAMA Neurol 2013 Sep 01;70(9):1133-1139 [FREE Full text] [doi: 10.1001/jamaneurol.2013.3216] [Medline: 23877059]

54. Zandi MS, Irani SR, Lang B, Waters P, Jones PB, McKenna P, et al. Disease-relevant autoantibodies in first episode schizophrenia. J Neurol 2011 Apr;258(4):686-688 [FREE Full text] [doi: 10.1007/s00415-010-5788-9] [Medline: 20972895]

55. Steiner J, Walter M, Glanz W, Sarnyai Z, Bernstein H, Vielhaber S, et al. Increased prevalence of diverse $\mathrm{N}$-methyl-D-aspartate glutamate receptor antibodies in patients with an initial diagnosis of schizophrenia: specific relevance of IgG NR1a antibodies for distinction from N-methyl-D-aspartate glutamate receptor encephalitis. JAMA Psychiatry 2013 Mar;70(3):271-278. [doi: 10.1001/2013.jamapsychiatry.86] [Medline: 23344076]

56. Pearlman DM, Najjar S. Meta-analysis of the association between N-methyl-d-aspartate receptor antibodies and schizophrenia, schizoaffective disorder, bipolar disorder, and major depressive disorder. Schizophr Res 2014 Aug;157(1-3):249-258 [FREE Full text] [doi: 10.1016/j.schres.2014.05.001] [Medline: 24882425]

57. Lennox BR, Palmer-Cooper EC, Pollak T, Hainsworth J, Marks J, Jacobson L, et al. Prevalence and clinical characteristics of serum neuronal cell surface antibodies in first-episode psychosis: a case-control study. The Lancet Psychiatry 2017 Jan;4(1):42-48 [FREE Full text] [doi: 10.1016/S2215-0366(16)30375-3] [Medline: 27965002]

58. Tarabeux J, Kebir O, Gauthier J, Hamdan FF, Xiong L, Piton A, S2D team, et al. Rare mutations in N-methyl-D-aspartate glutamate receptors in autism spectrum disorders and schizophrenia. Transl Psychiatry 2011 Nov 15;1:e55 [FREE Full text] [doi: 10.1038/tp.2011.52] [Medline: 22833210]

59. Creten C, van der Zwaan S, Blankespoor RJ, Maatkamp A, Nicolai J, van Os J, et al. Late onset autism and anti-NMDA-receptor encephalitis. The Lancet 2011 Jul 02;378(9785):98. [doi: 10.1016/S0140-6736(11)60548-5] [Medline: 21724038]

60. Hacohen Y, Wright S, Gadian J, Vincent A, Lim M, Wassmer E, et al. N-methyl-d-aspartate (NMDA) receptor antibodies encephalitis mimicking an autistic regression. Dev Med Child Neurol 2016 Oct 03;58(10):1092-1094 [FREE Full text] [doi: 10.1111/dmcn.13169] [Medline: 27255282] 
61. Tzang R, Chang C, Chang Y, Lane H. Autism Associated With Anti-NMDAR Encephalitis: Glutamate-Related Therapy. Front Psychiatry 2019 Jun 21;10:440 [FREE Full text] [doi: 10.3389/fpsyt.2019.00440] [Medline: 31293459]

62. Bailey A, Le Couteur A, Gottesman I, Bolton P, Simonoff E, Yuzda E, et al. Autism as a strongly genetic disorder: evidence from a British twin study. Psychol Med 1995 Jan 09;25(1):63-77. [doi: 10.1017/s0033291700028099] [Medline: 7792363]

63. Comi AM, Zimmerman AW, Frye VH, Law PA, Peeden JN. Familial clustering of autoimmune disorders and evaluation of medical risk factors in autism. J Child Neurol 1999 Jun 02;14(6):388-394. [doi: 10.1177/088307389901400608] [Medline: 10385847]

64. Sebat J, Lakshmi B, Malhotra D, Troge J, Lese-Martin C, Walsh T, et al. Strong association of de novo copy number mutations with autism. Science 2007 Apr 20;316(5823):445-449 [FREE Full text] [doi: 10.1126/science.1138659] [Medline: $17363630]$

65. Wang K, Zhang H, Ma D, Bucan M, Glessner JT, Abrahams BS, et al. Common genetic variants on 5p14.1 associate with autism spectrum disorders. Nature 2009 May 28;459(7246):528-533 [FREE Full text] [doi: 10.1038/nature07999] [Medline: 19404256]

66. Ronald A, Hoekstra RA. Autism spectrum disorders and autistic traits: a decade of new twin studies. Am J Med Genet B Neuropsychiatr Genet 2011 Apr 13;156B(3):255-274. [doi: 10.1002/ajmg.b.31159] [Medline: 21438136]

67. McCarron M, McCallion P, Reilly E, Mulryan N. A prospective 14-year longitudinal follow-up of dementia in persons with Down syndrome. J Intellect Disabil Res 2014 Jan;58(1):61-70. [doi: 10.1111/jir.12074] [Medline: 23902161]

68. Head E, Powell D, Gold BT, Schmitt FA. Alzheimer's Disease in Down Syndrome. Eur J Neurodegener Dis 2012 Dec;1(3):353-364 [FREE Full text] [Medline: 25285303]

69. Glasson EJ, Sullivan SG, Hussain R, Petterson BA, Montgomery PD, Bittles AH. The changing survival profile of people with Down's syndrome: implications for genetic counselling. Clin Genet 2002 Nov;62(5):390-393. [doi: 10.1034/j.1399-0004.2002.620506.x] [Medline: 12431254]

70. Turner HH. A syndrome of infantilism, congenital webbed neck, and cubitus valgus. Endocrinology 1938 Nov;23(5):566-574. [doi: 10.1210/endo-23-5-566]

71. Stochholm K, Juul S, Juel K, Naeraa RW, Gravholt CH. Prevalence, incidence, diagnostic delay, and mortality in Turner syndrome. J Clin Endocrinol Metab 2006 Oct;91(10):3897-3902. [doi: 10.1210/jc.2006-0558] [Medline: 16849410]

72. Cools M, Pleskacova J, Stoop H, Hoebeke P, Van Laecke E, Drop SLS, Mosaicism Collaborative Group. Gonadal pathology and tumor risk in relation to clinical characteristics in patients with 45,X/46,XY mosaicism. J Clin Endocrinol Metab 2011 Jul;96(7):E1171-E1180. [doi: 10.1210/jc.2011-0232] [Medline: 21508138]

\section{Abbreviations \\ ADHD: attention-deficit/hyperactivity disorder \\ ASD: autism spectrum disorder \\ CNV: copy number variation \\ HPO: human phenotype ontology \\ NMDAR: N-methyl-D-aspartate receptor \\ REDCap: Research Electronic Data Capture}

Edited by G Eysenbach; submitted 13.10.20; peer-reviewed by AJ Nagarajan; comments to author 20.11.20; revised version received
26.12.20; accepted 16.01.21; published 16.03.21
Please cite as:
Li J, Hojlo MA, Chennuri S, Gujral N, Paterson HL, Shefchek KA, Genetti CA, Cohn EL, Sewalk KC, Garvey EA, Buttermore ED,
Anderson NC, Beggs AH, Agrawal PB, Brownstein JS, Haendel MA, Holm IA, Gonzalez-Heydrich J, Brownstein CA
Underrepresentation of Phenotypic Variability of 16 p13.11 Microduplication Syndrome Assessed With an Online Self-Phenotyping
Tool (Phenotypr): Cohort Study
J Med Internet Res $2021 ; 23(3): e 21023$
URL: $\underline{\text { https://www.jmir.org/2021/3/e21023 }}$
doi: $\underline{10.2196 / 21023}$
PMID: $\underline{33724192}$

(CJianqiao Li, Margaret A Hojlo, Sampath Chennuri, Nitin Gujral, Heather L Paterson, Kent A Shefchek, Casie A Genetti, Emily L Cohn, Kara C Sewalk, Emily A Garvey, Elizabeth D Buttermore, Nickesha C Anderson, Alan H Beggs, Pankaj B Agrawal, John S Brownstein, Melissa A Haendel, Ingrid A Holm, Joseph Gonzalez-Heydrich, Catherine A Brownstein. Originally published in the Journal of Medical Internet Research (http://www.jmir.org), 16.03.2021. This is an open-access article distributed under the terms of the Creative Commons Attribution License (https://creativecommons.org/licenses/by/4.0/), which permits unrestricted 
use, distribution, and reproduction in any medium, provided the original work, first published in the Journal of Medical Internet Research, is properly cited. The complete bibliographic information, a link to the original publication on http://www.jmir.org/, as well as this copyright and license information must be included. 